\title{
CONTINUOUS PROFESSIONAL LEARNING IN PRIVATE HIGHER EDUCATION: MAKING A CASE FOR DISTRIBUTED LEADERSHIP
}

\author{
F. Cronje \\ Vega School of Design \\ Cape Town, South Africa \\ e-mail: francicronje@gmail.com
}

\section{E. M. Bitzer}

Centre for Higher and Adult Education

Stellenbosch University

Stellenbosch, South Africa

e-mail: emb2@sun.ac.za

\section{ABSTRACT}

Literature on management of professional learning in South African private higher education (PHE) institutions is limited. This may be due to incentives for professional learning in private higher education not being highly revered. Our article reports on the findings of research conducted on four campuses of a South African private higher education provider, inquiring into broadening organisational leadership roles towards distributed leadership. Findings show that academic managers in PHE see the proper educational induction of academics as a contributing factor to professional and institutional cohesion. However, the role of academic managers in designing custom-made professional learning initiatives is pivotal. Our findings confirm that academic managers in PHE contexts need to spend considerable effort on strategising their campus programmes to empower academic leaders through distributed leadership and with agency to lead their teams. We suggest a course of action for enhancing continuous professional learning (CPL) for academic staff in PHE: Firstly, academic management positions should be filled with the most competent people; secondly, academic managers should be directly accountable for the quality of professional learning on their campuses; and thirdly, academic managers need increased agency to use resources such as monetary and other incentives to support their academic teams.

Key words: continuous professional learning, academic managers, private higher education

\section{INTRODUCTION}

The importance of academic professional development has been well documented (Amundsen and Wilson 2012; Boud and Brew 2013; Knight, Tait and Yorke 2006). In the spirit of academic environments as learning communities, institutions have been moving away from traditional views of professional development initiatives towards the notion of continuous professional learning (CPL) (Webster-Wright 2009). 
In this article we report on research that regard academic campus managers as key in enabling professional learning initiatives in private higher education (PHE) institutions. The unique insider position of one of the authors enabled her to determine the current state and future prognosis of professional learning in one multi-campus PHE institution. Our research gave four academic campus managers the opportunity to critically reflect on their own practices and their management of continuous professional learning at their respective campuses. An iterative participative action research process led to important insights that might serve as a blueprint for professional learning as a strategy for improving the effectiveness of academic (lecturing/educator) staff in contexts where CPL is non-existent or limited. The article discusses particularly the experiences and privileged views of academic campus managers and their perceptions of the staff they lead, since they deal closely with their academic staff's output and personal needs on a daily basis.

\section{CONTEXTUALISING THE PROBLEM}

Although the South African government provides large amounts of money towards higher education provision in the country, the demand outstrips the provision. PHEIs are seen to fill a necessary void in this landscape, provided that the level and quality of provision be equal to that offered in the public higher education sphere (Boshoff 2014).

Currently there are more than a hundred private higher education institutions in South Africa. Private providers have historically, in a less regulated environment been regarded as "inferior institutions" (South Africa Council on Higher Education 2016, 149). The Higher Education Act gazetted in 2002 however, required PHEI programmes to be registered and accredited by the Higher Education Quality Committee (South Africa Council on Higher Education 2016). The quality assurance required registered programmes to be taught by lecturing staff with appropriate one-up academic qualifications. These stringent requirements also place an equal amount of stress on lecturing staff and therefore, the need for continuous professional learning initiatives have increased in these institutions.

\section{CPL IN THE SOUTH AFRICAN CONTEXT}

Staff development has a well-entrenched history in South African higher education, dating back to the 1970's and "is usually understood in terms of processes, structures and programmes that are aimed at harmonising individual and institutional interests towards mutual growth" (Botha and Potgieter 2009, 251).

The need for academic professional development has originated because practitioners contracted into teaching in the higher education environment are usually highly skilled field 
experts with little knowledge of the scholarship of teaching and learning (Cilliers and Herman 2010). The problem is that a "good academic practitioner" in higher education is described as an academic with "strong interpersonal relationships, advanced presentation skills, expert subject knowledge, a dynamic personality and the ability to mediate the so-called teaching/research nexus" (Van Schalkwyk et al. 2011, 140). Field experts however, are largely not skilled and experienced educators. Academic professional development and communities of inquiry are however, mentioned as one of the top ten key issues of Teaching and Learning for 2016 (Educause 2016).

Webstock and Sehoole (in South African Council on Higher Education 2016) describe two main issues that impacted on staffing in South African higher education during the last twenty years. Firstly, there has been a pull towards local democratisation to eradicate the historical issues around race and other inequalities, and secondly, the global push toward efficient massification. Much emphasis is placed on correcting the demographic compilation of staff, to accurately reflect that of the South African society. Early governmental policy goals required that three-year equity plans also included staff development initiatives. A global trend of managerialism in higher education soon added to these local issues (South Africa Council on Higher Education 2016).

South Africa is no exception when it comes to staff who are not always keeping in step with a rapidly changing student profile. Additionally, as also seen globally, a basic pedagogical knowledge is not a prerequisite for teaching in higher education. South African tertiary institutions have, however been focusing on professional development to upskill practitioners to teach effectively into underprepared and increasingly diverse undergraduate student populations. Often, these programs however, suffer from low uptake because of poor planning and roll-out strategies (Webstock and Sehoole in South Africa Council on Higher Education 2016).

Academic professional learning initiatives can easily be regarded as merely another imposition on an educator's time. Lecturers, especially recently inducted ones, are expected to comply with teaching practice criteria and pressures such as adhering to clear goals, adequate preparation, appropriate methods, significant student learning results, effective facilitation skills, and reflective critique (Frick and Kapp 2006, 87), which can limit their scholarly work. Under such pressures, especially in private higher education institutions, it thus remains challenging for lecturers to see the long term benefits of professional learning for teaching.

This South African PHEI has four campuses in major cities. The institute's professional environment resonates with literature arguing that academic professional learning needs to happen within a practice framework and without taking lecturers out of their teaching-learning 
environments (Boud and Brew 2013; Ferman 2002). In the PHEI each lecturing team on the four campuses is managed by an academic campus manager. Rosser describes these midlevel leaders and their particular challenges as the "unsung professionals of the academy" (Rosser 2004, 317). Rosser's (2004) conceptual framework highlights staff morale, staff satisfaction, and the intent to leave. These issues, if translated within the PHEI environment, are similar to the ones academic campus managers are faced with. Yet, a limited, even non-existent body of research exists on the role of midlevel managers in professional learning initiatives within private higher education.

\section{THEORETICAL PERSPECTIVES}

The quality and effectiveness of educators' teaching practices is widely considered as an institutional responsibility. However, literature shows that educational practitioners are better motivated when they can identify and act upon their own needs within real and practice-based teaching and learning environments (Altbach, Reisberg and Rumbley 2009; Blackmore and Blackwell 2003).

Both academic managers and educators continue to experience challenges such as increased student numbers, new information technologies demanding new teaching methodologies, a wider range of programme offerings driven by global student demand, and an ever-increasing sophistication of research activities (Paterson and Cloete 2018; Marshall et al. 2000). Global changes towards a stronger focus on student-centered learning, more demanddriven, interdisciplinary education and training, and a sophisticated mix of stakeholder demands are some of the dynamics that foreground the need for promoting CPL in higher education (Gillard 2004).

Academic professional learning has been reported as an important measure to enhance the synergy between academic staff and their institution (Herman 2015). Well-designed and concerted CPL efforts can assist in fostering trust and enhancing the motivation of academic practitioners. Earlier, James (1997) observed that “... [a university] cannot literally develop people; rather, people are the university, and it is their learning and its influence within a social context that modifies the university's goals, priorities and strategies for action" (James 1997). Frick and Kapp (2006) also underscore a holistic approach to professional learning as a way of synergising efforts between the university and its academic staff complement.

\section{The need for professional learning}

Cobb and Bowers (1999) highlight a number of qualities that practicing teaching professionals should be able to demonstrate. These include pedagogical and andragogical knowledge, a sound 
knowledge of disciplinary content, and excellent skills to facilitate learning. Academics should also be good communicators with a sound understanding of academic ethics and positive attitudes towards lifelong learning (Frick and Kapp 2006).

The need for inter-professional learning and sharing good educational practices (Johnson and Hirt 2011; Clarke and Reid 2013) resonates with competitive educational environments. Often, however, academics might feel time constrained and pressurised, while professional learning initiatives can easily be seen as an additional "burden" (Herman 2015). Induction into scholarly practice criteria such as setting learning goals, preparing adequately, using facilitation strategies effectively, and being able to reflectively assess own educational practices (Higgins 2011) might hamper scholarly work. In private higher education it is thus the task of the academic campus manager to emphasise a larger vision of long term developmental benefits to practitioners already under immense pressures.

\section{REPOSITIONING ACADEMIC PROFESSIONAL LEARNING}

Academic professional learning within learning organisations comprise collaborative and needs-driven activities - preferably identified and initiated by academic staff themselves. This contrasts with a focus on training and development that suits the institution. Where traditional academic professional learning would imply centrally planned and workshop-based development, closely contextualised continuous professional learning rather refers to "... any experience where professionals consider they have learned" (Webster-Wright 2009, 703).

This view resonates with the practice turn as proposed by Boud and Brew (2013), which moves away from that which the institution needs, to what the practitioner does in his or her own teaching-learning environment, and where practice is integrated through linking thinking with doing and people with their contexts (Boud and Brew 2013, 12). Such practice-based growth resonates with private higher education where lecturers are faced with long teaching hours and few incentives for personal development and growth.

In a wider continuing professional education context, Mott (2000) concludes that developing professional expertise needs to take into account a constantly changing environment, where learning opportunities are offered within a community of practice to enable further future professional development. It steers away from what the institution requires and what practitioners might lack (the deficit model) towards addressing the skills and practices needed to get a professional job done (Boud and Brew 2013). Translated into teaching and learning within a private higher education context, this approach needs the steering hand of competent academic campus managers who take into account that professional learning is context sensitive and needs to be situated within a practitioner's own practices (Boud and Brew 
2013). This defies any blanket professional learning solution for an institution, emphasising professional learning activities designed by those in direct feel with the needs of academic practitioners.

\section{Narrow institutional views}

One should be mindful that professional learning initiatives are most effective when practitioners' needs are prioritised. Members of staff become demotivated and skeptical when they perceive an institution as either acting in its own interest instead of that of its practitioners, or using corrective measures instead of accumulating skills. This includes initiatives that are implemented in a "top-down" managerial fashion, rather than honouring the desire of practitioners to get involved in identifying and driving participative initiatives (D'Andrea and Gosling 2005; Darling-hammond and Wei 2009; Mårtensson, Roxå and Olsson 2011; Makunye and Pelser 2012; Steyn 2012).

Of particular interest for our inquiry was the narrow views that often dominate with institutional administrators (McKinney 2006) and unreceptive institutional cultures that pose risks for appointments and promotions (Webb 2009). As private higher education institutions experience the direct effects of rapid economic and social changes (Fullan 2007; WebsterWright 2009), the issue also arises as to the way these changes are introduced with staff in change-weary times (Hayward, Priestley and Young 2004; Webster-Wright 2009).

Academic leaders that situate, conceptualise, and introduce professional learning insensitively might endanger such initiatives. Referring to assumptions regarding professional development, Webster-Wright (2009) emphasises the departure from a deficit model of development, a lack of short-term goals, weak staff incentives, and insufficient loci of control (Ingvarson 1998). Overall, these fault lines are often based institutionally and are mostly influenced and orchestrated by leadership strategy as discussed in the next section.

\section{Leadership and managerial practices}

If leadership at different institutional levels is tightly driven by administrator views and priorities, academic staff might not understand the need for continuous professional learning (Webster-Wright 2009). They might experience mangers "to know best", whereby academic initiatives and autonomy might be eroded (D'Andrea and Gosling 2005), and a negative bureaucratic working context for professionals created (Sandholtz and Scribner 2006; WebsterWright 2009; Wood 2007). Such a situation is arguably relevant to private higher education institutions, where professional learning initiatives could easily be decontextualised and are prone to managerial and business priorities (Gravani 2007; Webster-Wright 2009). 
Referring to communities of practice, Van Schalkwyk et al. (2011) warn about the danger of being sidetracked by managerial concerns while continuous professional learning might be hindered by poor organisational structures and a lack of formal support (Crimmins, Oprescu and Nash 2017). When administrative and bureaucratic practices dominate academic leadership functions, academic professionals might become frustrated by inappropriate pedagogical discourse (Van Schalkwyk et al. 2011).

\section{PRIVATE HIGHER EDUCATION AND PROFESSIONAL LEARNING}

The importance of academic professional learning is increasingly recognised by private higher education internationally. Whereas private institutions in the United Kingdom have provided such learning opportunities for some time by introducing internal units for staff development (Middlehurst 2004), facilities and opportunities for professional learning in African private higher education institutions are considered to be limited (Varghese 2004).

Full-time academics in private higher education function in a business environment and are expected to keep to office hours with less affordances of academic and research leave. Time is often divided between students, management, and subject-related research to promote teaching and learning. Ballam $(2012,9)$ aptly highlights this point: "Teaching in these performative academic cultures means making peace with this searing tension between reflection and action which constantly challenges both the individual's and the organisation's integrity".

An overwhelming majority of lecturers joining academic teams in private higher education are experts in specific fields within their own professional industries. They need a depth of teaching knowledge acquired in a just-in-time, just-enough approach. Newcomers are often not properly inducted into the skills of lecturing or in scholarly conversation. Moreover, lecturers often fail to attain pedagogical content knowledge, “... the thoughtful combining of knowledge of disciplinary concepts, teaching methods, and creative reflection on how concepts and methods can be interwoven in ways that result in student learning" (Henderson 2009, 15).

Private higher education institutions commonly rely on independent contractors for a large part of their educator resources (Varghese 2004). Employment of educators often comprise casual contracts (Crimmins, Oprescu and Nash 2017); however, a study in Poland found that private education providers known to be successful were those that focus on employing independent practitioners with less interest in other institutions. They also supported academic development and provided staff with good equipment and infrastructure (Duczmal 2006).

Of all the reasons for driving academic development, the most pertinent one seems to be creating a reflexive educational environment (Ballam 2012; Boud and Brew 2013; Erlandson 
and Beach 2008; Webster-Wright 2009), accompanied by growing the scholarship of teaching and learning (Healy and Welchert 2012; Webster-Wright 2009), and building communities of practice (Viskovic 2006; Webster-Wright 2009) in higher education environments. This points to important lessons, also for private higher education contexts.

Our personal experience of private higher education environments has led to the observation that professional learning initiatives in these contexts face additional challenges, since they are essentially run on business models. As such, academics employed by private higher education institutions often perceive institutional expectations as unrealistic and even schizophrenic, which sparked an empirical inquiry into professional learning in a South African multi-campus private higher education institution.

\section{RESEARCH DESIGN}

One of the authors is employed by the PHEI, a provider that focuses on design, marketing and branding. As national blended learning manager, she is responsible for developing a culture of teaching and learning in the institution. This responsibility has continuously prompted her to reflect on the crucial question: "How do I improve what I am doing?" (McNiff, Lomax and Whitehead 1996, 11). As action research is about "individual meaning making" (Amundsen and Wilson 2012, 108) rather than institutional outcomes, the focus of the research in this case was on encouraging academic campus managers at the four campuses to design and build continuous professional learning solutions to fit their own campuses, rather than to develop a "blueprint" for all campuses. An empathic resonance methodology (Whitehead 2012), involving systematic negotiation and analysis, provided a close-up focus on professional learning reflections over the 2016 academic year.

In the first participative action research cycle (PAR 1) the intervention comprised a workshop on each of the four campuses for both teaching staff $(n=73)$ and academic managers $(n=4)$. The participants were introduced to literature on professional learning related to public higher education institutions (Boud and Brew 2013; Coffey and Gibbs 2000; D'Andrea and Gosling 2005; Ferman 2002; Van Schalkwyk et al. 2011), and were then asked to identify their own motivational preferences and frustrations with their educational practices. Their reported frustrations included a lack of sufficient time to prepare for teaching, too little time to conduct professionally-related research, and a void in development within areas of expertise - in their own disciplines, as well as in scholarly teaching and learning. They also regarded leadership as often "disconnected" from academic practitioners, with poor communication between leadership and academic practitioners to add.

In the second research cycle (PAR 2) the research shifted towards the participating 
academic campus managers $(n=4)$ where they had to identify and implement instruments and activities developed and negotiated during the first cycle. The managers also discussed the progress of their campuses with each other during bi-weekly academic management telephonic communication meetings. Although these discussions were not tracked verbatim, it served the purpose of keeping the CPL agenda alive and facilitating discussions on various campus based initiatives. In between organisational and operational challenges, which usually consume many meeting hours, the peer partnering and peer reviews, as well as the use of teaching portfolios became regular points of discussion.

During the third and final research cycle (PAR 3) academic campus managers $(n=4)$ reflected on particular successes and failures of the previous year's work during individual interviews. These open-ended question interviews were thematically analysed according to the driving and inhibiting factors that affect the successful implementation of CPL initiatives, as reported by relevant literature.

Consistent and full participation by academic campus managers was important in this project. Their reflection in action (Mcniff et al. 1996) enabled perceptual insights regarding the direction of initiatives such as peer reviews, mentorships, teaching portfolios, and tool workshops, as well as the influence of inside and outside factors on the success of each of these initiatives.

Constant reflexive analysis and reporting (Guillemin and Gillam 2004) became a driving reality in the research project because of the potential sensitivity created by one of the authors' position as part of the national leadership team. In essence: Every academic campus manager became directly responsible for all academically related on-site activities, such as recruiting and overseeing academic staff, timetables, teaching and learning development, managing student support staff, and maintaining contact with students. Academic campus managers thus ultimately took responsibility for the smooth running of academic operations for both staff and students, which complexified their functions and often split their time between operational academic functions and teaching and learning activities. Data production in the project culminated into academic campus managers reflecting on their professional development initiatives and journeys across the four participating campuses of the PHEI during the 2016 academic year. Due to ethical considerations, the four campuses, situated in Johannesburg, Pretoria, Durban and Cape Town, were coded and will hereafter be randomly indicated as Campus A, B, C and D. Furthermore, pseudonyms applied as follows: the academic manager of Campus A is referred to as Arlene, that of Campus B as Beryl, Campus C as Cindy, and Campus D as Dorian. 


\section{FINDINGS AND DISCUSSION}

With practitioners who are experts in their fields, the challenge remains of creating career paths without losing sight of function or excellence. It is essential to consider the role and distribution of leadership within organisations by broadening teacher leadership roles towards distributed leadership models (Fullan 2007), and to create ways of decentralising management to enable the building of self-management capabilities and innovation (Drucker 2014).

\section{Centralised support}

At the PHEI it is positive that management is decentralised into the various campuses, and that academic campus managers work closely in their campus management teams with the head of campus. This effectively broadens teacher leadership roles towards distributed leadership models (Fullan 2007), with a mostly successful decentralisation when appropriate structures are in place. The structure fails, however, when one of the aspects is not functioning optimally. Yet, when management roles are properly fulfilled, positive outcomes are more likely to occur. Building self-management capabilities (Pask and Joy 2007) has thus been proved as imperative.

Regarding material mediation (Boud and Brew 2013), the School is adequately resourced. Yet, the impact of seemingly small issues, for instance IT provision, is clear on campus D, where the whole geographic region is struggling with provision. Concerning the relational importance that Boud and Brew (2013) refer to, these emerging issues have a strong impact. The capabilities of academic campus managers, including the social engineering that needs to be done by them, thus emerges as a pivotal aspect. A major insight was that the academic campus manager should be regarded as a main resource of the campus. This is proved, for instance, by the lack of teaching and learning events on Campus A, where Arlene was absent for three months during the time of research, and Dorian's focus on human resource issues which diverted her attention away from teaching and learning facilitation. She notes: "The whole staff shortage on this campus has been a nightmare this year ... I was the whole time sorting out problems ... It had a ripple effect because we work as a team, if someone is not doing workshops or following up to pick it up."

\section{Fostering an enabling distributed leadership environment}

The academic campus manager has a critical function in ensuring the effective strategising and roll-out of professional learning initiatives. This managerial role resonates closely with the creation of an enabling environment as described by Van Schalkwyk et al. (2011), which encourages peer discussion and reflection on pedagogical practices, with ample time to acknowledge and argue theoretical points around scholarly teaching practice. When academic 
campus managers activate such spaces, some practitioners can move higher up in the scholarship of the Teaching and Learning (SoTL) framework (Van Schalkwyk et al. 2011) "to be recognised by peers as contributing to an important larger enterprise" where attention is paid to critical matters, including workload (Van Schalkwyk et al. 2011, 9). One academic campus manager commented as follows: "I want to say, in a professional conduct, to say give me your hours, I'll see how I can fit it, and we will work it that way".

Considering Boud and Brew's practice turn (2013), independent contractors across campuses seem to be particularly in tune with both their professional and teaching practice. Although a rift exists between permanent and casual members of staff on the largest campus, it can be solved by better introduction and motivation. Academic campus managers need to engineer better introductions and pairing of individuals during more integrated inductions.

\section{Strategically contextualising interesting and challenging tasks}

Contextualisation also emerged as key in overall motivation. All four participants recalled instances where inadequate contextualisation managed to derail the process of adoption. Equally important is the introduction of interesting and challenging tasks. Whereas Beryl, academic campus manager on Campus $\mathrm{B}$, found her independent contractors more willing to engage in interesting tasks, Cindy, academic campus manager on Campus $\mathrm{C}$, located all tasks in the interest of a branding school, which caught the attention of the overall cohort of staff. Although tasks should not only be interesting, but also challenging (Boud and Brew 2013), Beryl observed that lecturers find these challenging tasks more daunting than anticipated. She emphasised: "I did not expect that they will struggle so much with classroom management, especially not those experienced lecturers. But class management was rather a big thing, especially the bigger classes."

She therefore micro-designed tasks further by concentrating on smaller steps, and by putting more detail into each bigger task. Not formalising tasks in view of a bigger goal tripped Arlene up with introducing teaching tools, while Beryl and Cindy, being more strategic in thinking and designing for the bigger goal, achieved more success.

Tailor-made tasks are effective only if they are activated in a holistically productive bigger plan. This is why Arlene's loosely structured tools did not impact significantly. Crosspollination between permanent and casual members of staff was most effective on Campus $\mathrm{C}$, where Cindy strategically and conceptually paired people with the idea of cross-disciplinary collaboration.

Cindy's efforts emerged strongly regarding the integration of subject knowledge with teaching principles, as described by one of Frick and Kapp's six principles of building a 
successful professional learning programme (2006). Her design of teaming up lecturers from various disciplines succeeded to not only integrate subject knowledge with teaching principles better, but also to spread the school-specific way of teaching as navigation through a wider group of staff. The literature repeatedly refers to the importance of practitioners managing themselves (Frick and Kapp 2006; Mohrman, Mohrman and Odden 1997). Three of the four academic campus managers in this study mentioned that they prefer lecturers being independent and able to manage their students independently. Cindy and Beryl particularly described how they tried to ensure that lecturers choose their own mentoring partners and conduct their professional development tasks at their own pace. Allowing this type of agency, Beryl believed, would foster confidence and belief in themselves and their own abilities. Her desire is that practitioners would think "Oh, you know, I am actually trusted and appreciated, I know what I am doing and that I am doing good work; I also know I have areas where I can improve but it's all about making me grow at the end of the day".

\section{Leader agency with accountability}

An individual approach to broader principles emerged with the four academic campus managers' varying approaches to self-reflection. Whereas Arlene encouraged individual reflection, Beryl designed a collective focus on communities of practice and how self-reflection will play out on a broader landscape, while Cindy integrated self-reflection as one of the aspects incorporated in peer partnerships. This aspect did not emerge at all in Dorian's interview. The issue of internal motivation was only introduced in the interview with Beryl when discussing independent contractors and their need for input after class visits. She also described independent contractors as being highly driven.

All four academic managers had been providing opportunities for professional learning, albeit in different forms and at different tempos. Clearly, however, good intentions are not the discerning success factor and all leadership aspects as they emerged from the findings together create a more conducive institutional environment for sustained successful professional learning. Clearly personal and team attributes need to be supported by strong institutional structures.

Particular aspects that emerged and are related to professional learning success were human resource infrastructure and support, uninterrupted IT provision, and most importantly, the leadership and initiative of the academic campus manager as a pivotal figure to drive continuous professional learning. This critical function of leadership clearly needs the full support of central management, with sufficient decentralised agency for a manager to find tailor-made solutions for the needs of a particular campus. Such support for campus leaders 
seem to include possibilities for reward to staff who perform excellently, including casual staff.

\section{Implications of the research}

This article has discussed research potentially useful for the successful implementation of continuous professional learning in a private higher education context. Based on our findings, the following important points emerged:

- Adequately qualified academic campus managers in private higher education are needed to drive the continuous professional learning of campus staff. This point is strongly supported by several authors, including Meek, Teichler and Kearney (2009), who have advocated for leadership responsibility for academic professional learning initiatives and activities.

- Central private higher education leadership needs to provide adequate material resources to campus leaders to run their campuses. For instance, they need a central scholarly support system whereby knowledge resources are made available to managers. This includes the appointment of a national learning and teaching expert who is dedicated to provide scholarly support, drive the professional learning of academic staff and by support structures for academic campus managers without inhibiting individual agency and initiative. Such a strategy was also supported and highlighted earlier by authors such as Boud and Brew (2013) in international contexts.

- From our research, and as supported by relevant literature (e.g Pink 2011; Agyemang and Broadbent 2015) the need also became clear for academic campus managers to be empowered to recruit appropriately qualified and experiences academic staff by having more control over salary package negotiations and campus-specific structures. This implies more control over the individual campus budgets, with a clear understanding and responsibility to be held to accountable for professional learning expenditure and results.

- Our project has shown that academic campus managers need to account for professional learning as a rigorous process on a regular basis. This point was strongly driven home by authors such as Marshall et al. (2000) who had indicated that this accountability needs to be separated from, and over and above of, the student learning and teaching programme. This rigorous accountability process might also imply, for instance, that an academic campus manager be contracted for a three-year cycle with clear of performance criteria being met before a further contract can be awarded.

In conclusion, we suggest that the adequate empowerment of academic campus managers on 
the level of individual campuses might limit the inhibiting factors that are currently dampening efforts towards the continuous professional learning of academic staff. These factors include the reigning perception of managerialist practices and, in particular, the "helicopter-type" management style from national leadership. Campus managers, in turn, should be held accountable for solid plans and structures for such learning on their respective campuses. The elements of a complete campus plan for CPL need to be properly introduced and contextualised for all staff on each and every private higher education campus. This would significantly strengthen the efforts towards effective leadership for CPL and which might serve as a researched-based model for similar South African institutions.

\section{REFERENCES}

Agyemang, G. and J. Broadbent. 2015. Management control systems and research management in universities. Accounting, Auditing \& Accountability Journal 28(7): 1018-1046. doi: 10.1108/AAAJ-11-2013-1531.

Altbach, P. G., L. Reisberg and L. E. Rumbley. 2009. Trends in global higher education: Tracking an academic revolution. UNESCO 2009 World Conference on Higher Education. UNESCO Pub. http://unesdoc.unesco.org/images/0018/001832/183219e.pdf

Amundsen, C. and M. Wilson. 2012. Are we asking the right questions?: A conceptual review of the educational development literature in higher education. Review of Educational Research 82(1): 90-126. SAGE Publications. doi: 10.3102/0034654312438409.

Ballam, J. 2012. "Driving lessons - supporting academic development in a private higher education space." Durban: Independent Education Institute. http://iiespace.iie.ac.za:80/handle/12345 6789/16 (Accessed 4 May 2015).

Blackmore, P. and R. Blackwell. 2003. Towards strategic staff development in higher education. Abington: Open University Press.

Boshoff, A. 2014. Professional development of academic staff in private higher education. Doctoral dissertation, University of Pretoria.

Botha, L. S. and F. J. Potgieter. 2009. Understanding skills development in South African higher education institutions. South African Journal of Higher Education 23(2): 246-263.

Boud, D. and A. Brew. 2013. Reconceptualising academic work as professional practice: Implications for academic development. International Journal for Academic Development. 18(December 2013): 1-14. Taylor \& Francis. doi: 10.1080/1360144X.2012.671771.

Cilliers, F. J. and N. Herman. 2010. Impact of an educational development programme on teaching practice of academics at a research-intensive university. International Journal for Academic Development 15(3): 253-267. doi: 10.1080/1360144X.2010.497698.

Clarke, C. and J. Reid. 2013. Foundational academic development: Building collegiality across divides? International Journal for Academic Development 18(December 2013): 1-13. Taylor \& Francis. doi: 10.1080/1360144X.2012.728529.

Clegg, S. 2003. Problematising ourselves: Continuing professional development in higher education. International Journal for Academic Development 8(1-2): 37-50. doi: $10.1080 / 1360144042000277928$.

Cobb, P. and J. Bowers. 1999. Cognitive and situated learning perspectives in theory and practice. Educational Researcher 28(2): 4-15.

Coffey, M. and G. Gibbs. 2000. Can academics benefit from training? Some preliminary evidence. Teaching in Higher Education 5(3): 385-389. 
Crimmins, G., F. Oprescu and G. Nash. 2017. Three pathways to support the professional and career development of casual academics. International Journal for Academic Development 1324(January): 1-13. Routledge. doi: 10.1080/1360144X.2016.1263962.

D'Andrea, V. and D. Gosling. 2005. Improving teaching and learning in higher education: A whole institution approach. Berkshire: McGraw-Hill International.

Darling-Hammond, L. and R. C. Wei. 2009. Professional learning in the learning profession: A status report on teacher development in the United States and abroad. Technical Report: National Staff Development Council. Dallas, Texas.

Dearn, J. 2005. The role and impact of faculty development on learning and teaching outcomes in higher education. Educational Developments 6(1): 1-11.

Drucker, P. F. 2014. Innovation and entrepreneurship. Routledge.

Duczmal, W. 2006. The rise of private higher education in Poland: Policies, markets and strategies. Centre for Higher Education Policy Studies, Enschede, The Netherlands.

Educause. 2016. The 2016 key issues in teaching and learning. Educause Center for Applied Resarch. http://www.educause.edu/eli/initiatives/key-issues-in-teaching-and-learning (Accessed 5 March 2016).

Erlandson, P. and D. Beach. 2008. The ambivalence of reflection - rereading Schon. Reflective Practice: International and Multidisciplinary Perspectives 9(4): 409-421. doi: 10.1080/14623940802475843.

Ferman, T. 2002. Academic professional development practice: What lecturers find valuable. International Journal for Academic Development 7(2): 146-158. Taylor \& Francis. doi: 10.1080/1360144032000071305.

Frick, L. and C. Kapp. 2006. Continuing Professional Development (CPD) of lecturers in the natural sciences: Enhancing the quality of learning. Education as Change 10(2): 81-96. Taylor \& Francis. doi: $10.1080 / 16823200609487141$.

Fullan, M. 2007. Change theory as a force for school improvement. Intelligent Leadership: Constructs for Thinking Education Leaders (157): 27-39. doi: ISBN 1920963359.

Gillard, E. 2004. Report on the colloquium on 10 years of democracy and higher education change. Glenburn Lodge, Muldesdrift: Council on Higher Education. (Accessed 12 November 2005).

Gravani, M. N. 2007. Unveiling professional learning: Shifting from the delivery of courses to an understanding of the processes. Teaching and Teacher Education 23(5): 688-704. doi: 10.1016/j.tate.2006.03.011.

Guillemin, M. and L. Gillam. 2004. Ethics, reflexivity, and "ethically important moments" in research. Qualitative Inquiry 10(2): 261-280. doi: 10.1177/1077800403262360.

Hayward, L., M. Priestley and M. Young. 2004. Ruffling the calm of the ocean floor: Merging practice, policy and research in assessment in Scotland. Oxford Review of Education 30(3): 397-415. doi: 10.1080/0305498042000260502.

Healy, C. C. and A. J. Welchert. 2012. Relations: Mentoring definition to advance. Educational Research 19(9): 17-21. doi: 10.1104/pp.002816.gence.

Henderson, B. B. 2009. Beyond Boyer: SoTL in the context of interesting scholarly things. InSight: A Journal of Scholarly Teaching 4: 12-20. ERIC.

Herman, N. 2015. The role of context in decision making about professional learning by lecturers at a research-intensive university. Stellenbosch University.

Higgins, D. 2011. Why reflect? Recognising the link between learning and reflection. Reflective Practice 12(5): 583-584. doi: 10.1080/14623943.2011.606693.

Ingvarson, L. 1998. Teaching standards: Foundations for professional development reform. In International handbook of educational change, 1006-1031. Springer.

James, R. 1997. An organizational learning perspective on academic development: A strategy for an uncertain future. International Journal for Academic Development 2(February 2015): 35-41. doi: 


\section{$10.1080 / 1360144970020206$}

Johnson, A. T. and J. B. Hirt. 2011. Reshaping academic capitalism to meet development priorities: The case of public universities in Kenya. Higher Education 61(4): 483-499. doi: 10.1007/s10734-0109342-6.

Knight, P., J. Tait and M. Yorke. 2006. The professional learning of teachers in higher education. Studies in Higher Education 31(3): 319-339.

Makunye, M. M. and T. G. Pelser. 2012. Academic staff's apathy towards formal professional development programmes at North-West University. South African Journal of Higher Education 26(3): 529-545.

Marshall, S., M. Adams, A. Cameron and G. Sullivan. 2000. Academics' perceptions of their professional development needs related to leadership and management: What can we learn? International Journal for Academic Development 5(1): 42-53. doi: 10.1080/136014400410097.

Mårtensson, K., T. Roxå and T. Olsson. 2011. Developing a quality culture through the Scholarship of Teaching and Learning. Higher Education Research \& Development 30(1): 51-62. doi: 10.1080/07294360.2011.536972.

McKinney, K. 2006. Attitudinal and structural factors contributing to challenges in the work of the scholarship of teaching and learning. New Directions for Institutional Research 129(Spring): 3750. doi: 10.1002/ir.

McNiff, J., P. Lomax and J. Whitehead. 1996. You and your action research project. London: Routledge \& Hyde Publications.

Meek, V. L., U. Teichler and M. Kearney. 2009. Higher Education, Research and Innovation: Changing Dynamics Report on the UNESCO Forum on Higher Education, Research and Knowledge. Kassel: UNESCO Forum on Higher Education.

Middlehurst, R. 2004. Governance: A discussion of leadership roles and management structures in UK universities. Higher Education Quarterly 58(4): 258-279.

Mohrman, A. M., S. A. Mohrman and A. R. Odden. 1997. Aligning teacher compensation with systemic school reform: Skill-based pay and group-based performance rewards. American Education Research Journal 18(1): 51-71.

Mott, V. 2000. The development of professional expertise in the workplace. New Directions for Adult and Continuing Education 2000(86): 23-32. doi: 10.1002/ace.8603.

Paterson M and N. Cloete. 2018. Protecting universities' knowledge-production mandate. University World News 31 August.

Pask, R. and B. Joy. 2007. Mentoring-coaching: A guide for education professionals. New York: McGraw Hill Education.

Pink, D. H. 2011. Drive: The surprising truth about what motivates us. Penguin.

Rosser, V. J. 2004. A national study on midlevel leaders in higher education: The unsung professionals in the academy. Higher Education 48(3): 317-337. doi: 10.1023/B:HIGH.0000035543.58672.52.

Sandholtz, J. H. and S. P. Scribner. 2006. The paradox of administrative control in fostering teacher professional development. Teaching and Teacher Education 22(8): 1104-1117. Elsevier. doi: 10.1016/j.tate.2006.07.006.

South Africa Council on Higher Education. 2016. South African higher education reviewed: Two decades of democracy, Che. doi: 10.1080/02642060701453288.

Steyn, G. M. 2012. Reframing professional development for South African schools: An appreciative inquiry approach. Education and Urban Society 44(3): 318-341. doi: $10.1177 / 0013124510392569$.

Van Schalkwyk, S., F. Cilliers, H. Adendorff, K. Cattell and N. Herman. 2011. Journeys of growth towards the professional learning of academics: Understanding the role of educational development. International Journal for Academic Development 18(2): 139-151. doi: 10.1080/1360144X.2012.673490. 
Varghese, N. V. 2004. Private higher education in Africa. International Institute for Educational Planning, Paris. A UNESCO Report.

Viskovic, A. 2006. Becoming a tertiary teacher: Learning in communities of practice. Higher Education Research and Development 25(4): 323-399. doi: 10.1080/07294360600947285.

Webb, C. 2009. Evaluation of the Teaching Quality Indicators Project. A national project of the Australian Learning and Teaching Council. May.

Webster-Wright, A. 2009. Reframing professional development through understanding authentic professional learning. Review of Educational Research 79(2): 702-739. Sage Publications. doi: $10.3102 / 0034654308330970$.

Whitehead, J. 2012. Educational research for social change with living educational theories. Educational Research for Social Change 1(1): 5-21.

Wood, D. 2007. Teachers' learning communities: Catalyst for change or a new infrastructure for the status quo? Teachers College Record 109(3): 699-739. doi: 10.1177/002248717502600425. 